\title{
Bone mineral changes during pregnancy: a cross-sectional study
}

\author{
Ritu Sharma ${ }^{1}$, Deepali Garg ${ }^{1 *}$, Huma Khan ${ }^{2}$
}

\begin{abstract}
${ }^{1}$ Department of Obstetrics and Gynecology, Government Institute of Medical Sciences, Greater Noida, Uttar Pradesh, India

${ }^{2}$ Department of Community Medicine, Shri Ram Murti Smarak Institute of Medical Sciences, Bareilly, Uttar Pradesh, India
\end{abstract}

Received: 24 April 2019

Accepted: 30 April 2019

\section{*Correspondence:}

Dr. Deepali Garg,

E-mail: drdeepaligarg@gmail.com

Copyright: (C) the author(s), publisher and licensee Medip Academy. This is an open-access article distributed under the terms of the Creative Commons Attribution Non-Commercial License, which permits unrestricted non-commercial use, distribution, and reproduction in any medium, provided the original work is properly cited.

\section{ABSTRACT}

Background: Changes in bone mineral density during pregnancy are not widely studied because of the risk of radiation hazard to the fetus. But newer technology like DEXA has made it possible to measure bone density accurately with low dose radiations which are safe even during pregnancy. The aim of this study was to evaluate the changes in maternal bone turnover markers and bone mineral content at forearm during pregnancy.

Methods: A total of 32 pregnant women with singleton pregnancy of more than thirty five weeks gestational age and thirty non-pregnant, non-lactating women as controls were recruited. Baseline blood investigations, serum calcium, serum alkaline phosphatase and DEXA of the forearm at ultra-distal, mid radius and proximal $1 / 3^{\text {rd }}$ of radius were done at the time of recruitment into the study.

Results: Bone mineral density of forearm of pregnancy group was compared with non-pregnant, non-lactating control group to see the effect of pregnancy. Bone turnover markers like serum calcium and serum ALP were also compared among pregnancy group and controls. The mean bone mineral density of controls at ultra-distal radius was $0.437 \pm 0.058 \mathrm{~g} / \mathrm{cm}^{2}$, while in pregnant women it was $0.431 \pm 0.58 \mathrm{~g} / \mathrm{cm}^{2}$ that was not statistically significant. Bone mineral density at mid radius in control was $0.599 \pm 0.051 \mathrm{~g} / \mathrm{cm}^{2}$ and in pregnant women it was $0.597 \pm 0.048 \mathrm{~g} / \mathrm{cm}^{2}$ with no significant difference. BMD at proximal $1 / 3^{\text {rd }}$ radius in controls was $0.670 \pm 0.36 \mathrm{~g} / \mathrm{cm}^{2}$ as compared to pregnant women where it was $0.660 \pm 0.036 \mathrm{~g} / \mathrm{cm}^{2}$ without any statistical significance. Total BMD at forearm in control and pregnant women was $0.586 \pm 0.035$ and $0.582 \pm 0.036$ respectively and again there was no statistically significant difference.

Conclusions: There is no significant impact of pregnancy on bone mineral density of forearm. Although more bone areas need to be investigated for the further confirmation.

Keywords: Bone mineral density, DEXA, Forearm, Pregnancy, Radius

\section{INTRODUCTION}

Bones not only provide mechanical support and decide the attributes of body size and shape but also play a very vital role in calcium and phosphorus homeostasis. Bone is a special connective tissue which is made up of organic matrix $(35 \%)$ composed of bone cells and the collagen protein and inorganic matrix $(65 \%)$ which is calcium hydroxyapatite. Calcium hydroxyapatite contains $99 \%$ calcium of the whole body. Bone is continuously kept on forming and resorbing and this process of bone formation and resorption is strictly controlled by multiple factors. When bone formation predominates then bone mass increases and when resorption predominates then bone mass decreases. Their balance determines bone mass at any point of time. BMD is predominantly determined by 
genetic factors and partly by environmental factors like pregnancy and lactation. Weight, BMI and lean body mass, fat content, physical activity are other factors which may also influence BMD. During pregnancy there is weight gain leading to increased mechanical load on maternal skeleton. There is also increase in fat content which leads to peripheral production of oestrogen, these factors affect bone mineral deposition in positive way.

Peak bone mass is probably most important determinant of risk of developing osteoporosis later in life. It is usually attained in third decade of life and at this time, bone formed and bone reabsorbed remain in equilibrium. After the age of thirty; the amount of bone resorbed exceeds than that what has been formed and there is a steady fall in the skeletal mass. Any disturbance in this equilibrium i.e. too fast resorption or too sluggish replacement results in osteopenia/ osteoporosis. Theoretically pregnancy is the time of physiological burden on calcium homeostasis as on one hand there is increased requirement for the developing foetus and on other hand there is increased demand for growing maternal tissues also.The developing foetus draws around $30 \mathrm{gm}$ calcium from the mother during entire pregnancy period; theoretically placing the mother at an increased risk for osteoporosis/osteopenia. ${ }^{1}$ Increased concentration of parathyroid hormone related peptide (PTHrP) is detected in the maternal circulation during pregnancy, probably originating from foetal, placental or mammary tissue. PTHrP can activate PTH / PTHrP receptors and can increase osteoclastic activity. It may contribute to rise of 1,25 dihydroxy vitamin D levels and may protect bones by inhibiting levels of PTH. Serum calcitonin levels are also show rise during pregnancy and they are produced by thyroid, breasts and placenta. They protects maternal skeleton from excessive bone resorption. ${ }^{2}$

During pregnancy, intestinal calcium absorption increases to meet much of the foetal calcium needs. The body also responds to increased foetal calcium demand by increasing total 1,25 dihydroxy vitamin D levels through up regulation of renal hydroxylation, extra renal synthesis or both in placental or foetal tissue. ${ }^{3}$ The third trimester oestrogen surge is also protective to bones.

We performed a cross sectional observational study to evaluate these changes in maternal bone metabolism by examining various parameters of bone metabolism like bone mineral density, serum alkaline phosphatase and serum calcium. We tried to find out co-relation of pregnancy with these changes in parameters.

\section{METHODS}

This was a cross-sectional observational case control study conducted on 32 pregnant women above eighteen years of age with singleton pregnancy with thirty five weeks or more gestational age and age-matched 30 non pregnant-non lactating controls attending an outpatient clinic at a tertiary care hospital for routine antenatal care and other gynaecological problems. The study was approved by the institutional ethical committee and written informed consent was obtained from all participating women. Study was conducted from April 2018 to December 2018. Women were thoroughly asked for any past medical or surgical history or drug history which could affect bone metabolism.

Exclusion criteria included women who had been pregnant or lactating in last 2 years, any metabolic and endocrinal abnormality affecting bone metabolism like mal-absorption, hyperthyroidism, hyper parathyroidism, Cushing disease, acromegaly, multiple pregnancy; systemic diseases like cardiac, hepatic or renal disease; women having radiation exposure, malignancy of bone or metastasis to bone; any other bone disease, fracture, prolonged immobilization due to any cause and musculoskeletal disorder. Subjects consuming drugs which are known to affect bone metabolism eg. hormones, corticosteroids, heparin were also excluded. Women included in the study were thoroughly interrogated for their obstetrical as well as gynaecological history regarding parity/gravidity, spacing between child births, complications in previous or present pregnancy like multiple pregnancy, number of children breast fed, average duration of breast feeding, mode of delivery, birth weight of baby etc. Disorders of menstruation or history of fibroid or any other gynaecological condition which show hyperestrogenism or affect hormonal balance were enquired. Past surgical history especially bone surgeries, bowel surgery and neck surgeries were excluded. Hormonal contraceptive usage was asked. Dietary history was asked in detail for dairy products consumption and calcium supplementation and total daily calcium consumption was calculated.

A thorough general examination was done with special attention to height, weight, BMI, icterus \& lymphadenopathy. Systemic examination especially of musculo-skeletal, endocrinal, respiratory, central nervous and cardiovascular system was done to rule out any systemic disease. Detailed obstetrical/ gynaecological examination was done in each case. All baseline blood investigations were done at the time of recruitment into the study.

In pregnancy group DEXA of forearm was done once at the gestational age $>35$ weeks after providing lead apron to the women. Three regions were specially looked for bone mineral density i.e. ultra distal radius (mainly cancellous), mid radius, proximal $1 / 3^{\text {rd }}$ radius (mainly cortical).

Serum calcium, serum albumin, serum alkaline phosphatase and serum thyroid stimulating hormone estimation was done once after inclusion into the study.

Bone mineral density was measured by DEXA using digital flash beam technology using collimated x-ray source to get a cone shaped beam of a bi-dimensional 
detector (2D detector). Bone mineral density was noted in $\mathrm{gm} / \mathrm{cm}^{2}$ and $\mathrm{T}$ - score and the results were interpreted as below.

\section{T score Interpretation \\ -1 or higher Normal \\ -1 to $-2.5 \quad$ Osteopenia \\ -2.5 or lower Osteoporosis}

Z-score is defined as difference between the patient's values and the mean value in a population of healthy subjects of same age, divided by the standard deviation. For women in reproductive age group T-score and Z scores are same.

\section{Statistical analysis}

The results in two groups were compared using chisquare test and student $\mathrm{t}$ - test. $\mathrm{P}$ value $<0.05$ was considered statistically significant.

\section{RESULTS}

There was no statistically significant difference between the two groups as far as demographic profile was concerned (Table 1). The mean bone mineral density of controls at ultra-distal radius was $0.437 \pm 0.058 \mathrm{~g} / \mathrm{cm}^{2}$, while in pregnant women it was $0.431 \pm 0.58 \mathrm{~g} / \mathrm{cm}^{2}$. There was $1.4 \%$ fall in BMD in pregnant women at ultra-distal radius but that was not stastically significant. Bone mineral density at mid radius in controls was $0.599 \pm 0.051 \mathrm{~g} / \mathrm{cm}^{2}$ and in pregnant women it was $0.597 \pm 0.048$ with no significant difference. BMD at proximal one third radius in controls was $0.670 \pm 0.36 \mathrm{~g} / \mathrm{cm}^{2}$ as compared to pregnant women where it was $0.660 \pm 0.036$ and there was $1.5 \%$ increase in BMD in pregnant woman without any statistical significance. Total BMD at forearm in control and pregnant women were not significantly different and were $0.586 \pm 0.035$ and $0.582 \pm 0.036$ respectively $(\mathrm{p}=0.76)$ (Table 2$)$.

The mean serum calcium in pregnant women was $2.28 \pm 0.065 \mathrm{mmol} / \mathrm{lit}$ as compared to $2.45 \pm 0.58 \mathrm{mmol} / \mathrm{lit}$ in controls and was significantly lower $(\mathrm{p}=0.001)$. Mean serum albumin concentration in pregnant women was $3.53 \pm 0.63 \mathrm{mg} / \mathrm{dl}$ as compared to $4.78 \pm 0.43 \mathrm{mg} / \mathrm{dl}$ in controls and was significantly lower $(\mathrm{p}=0.003)$.

Table 1: Comparison of demographic profile.

\begin{tabular}{|c|c|c|c|c|c|}
\hline Sr. No. & Parameter & $\begin{array}{l}\text { Pregnancy } \\
\text { group } \mathrm{N}=32\end{array}$ & $\begin{array}{l}\text { Control group } \\
\mathrm{N}=30\end{array}$ & $\begin{array}{l}\mathrm{p} \\
\text { value }\end{array}$ & $\begin{array}{l}\mathrm{t} \\
\text { value }\end{array}$ \\
\hline 1 & Age (year) & $25.62 \pm 4.35$ & $25.20 \pm 4.77$ & 0.79 & 0.26 \\
\hline 2 & Height (meter) & $1.52 \pm 0.023$ & $1.52 \pm 0.018$ & 0.80 & 0.26 \\
\hline 3 & Weight (kg) & $49.0 \pm 2.81$ & $49.4 \pm 2.59$ & 0.84 & 0.25 \\
\hline 4 & BMI $\left(\mathrm{kg} / \mathrm{m}^{2}\right)$ & $21.46 \pm 0.99$ & $21.32 \pm 1.11$ & 0.72 & 0.29 \\
\hline 5 & Parity & $1.0 \pm 1.39$ & $1.2 \pm 1.47$ & 1.2 & 0.14 \\
\hline 6 & Duration of breast feeding (months) & $12 \pm 16.69$ & $14.4 \pm 17$ & 0.69 & 0.39 \\
\hline 7 & Mean gestational age at the time of delivery (weeks) & $38.04 \pm 0.07$ & - & & \\
\hline 8 & Mean infant birth weight (kg) & $2.57 \pm 0.84$ & - & & \\
\hline 9 & Average daily calcium intake (mg/day) & 1636 & 1598 & & \\
\hline
\end{tabular}

Table 2: Comparison of mean bone mineral density of forearm.

\begin{tabular}{|lllll|l|}
\hline Sr. No. & Area of fore arm & $\begin{array}{l}\text { BMD in pregnancy } \\
\text { group }\left(\mathrm{g} / \mathrm{cm}^{2}\right)\end{array}$ & $\begin{array}{l}\text { BMD in control group } \\
\left(\mathrm{g} / \mathrm{cm}^{2}\right)\end{array}$ & $\begin{array}{l}\mathrm{p} \\
\text { value }\end{array}$ & $\begin{array}{l}\mathrm{t} \\
\text { value }\end{array}$ \\
\hline 1 & Ultra distal radius & $0.431 \pm 0.058$ & $0.437 \pm 0.049$ & 019 & 0.26 \\
\hline 2 & Mid radius & $0.597 \pm 0.048$ & $0.599 \pm 0.051$ & 0.98 & 0.56 \\
\hline 3 & Proximal $1 / 3^{\text {rd }}$ radius & $0.660 \pm 0.036$ & $0.670 \pm 0.036$ & 0.57 & 0.01 \\
\hline 4 & Total & $0.582 \pm 0.036$ & $0.586 \pm 0.035$ & 0.76 & 0.29 \\
\hline
\end{tabular}

Table 3: Comparison of biochemical parameters.

\begin{tabular}{|lllll|l|}
\hline Sr. No. & Biochemical parameter & Pregnancy group & Control group & p & $\begin{array}{l}\mathrm{t} \\
\text { value } \\
\text { value }\end{array}$ \\
\hline 1 & Serum calcium $(\mathrm{m} \mathrm{mol} / \mathrm{lit})$ & $2.28 \pm 0.065$ & $2.45 \pm 0.058$ & 0.001 & 7.55 \\
\hline 2 & Serum albumin $(\mathrm{mg} / \mathrm{dl})$ & $3.53 \pm 0.63$ & $4.78 \pm 0.43$ & 0.003 & 2.30 \\
\hline 3 & Serum ALP (IU/L) & $184 \pm 66.4$ & $73.5 \pm 45.7$ & 0.001 & 4.89 \\
\hline 4 & Serum TSH (m IU/L) & $1.83 \pm 1.99$ & $1.46 \pm 1.01$ & 0.56 & 0.57 \\
\hline
\end{tabular}


The mean serum alkaline phosphatase concentration in controls was $73.5 \pm 45.7 \mathrm{IU} / \mathrm{lit}$ as compared to pregnant women who has mean s. alkaline phosphatase $184 \pm 66.4$ IU/lit. Mean s. alkaline phosphatase concentration in pregnant woman was statistically higher $(\mathrm{p}=0.001)$ as compared to controls. Both controls as well as pregnant woman have serum TSH levels within normal limits and means serum TSH in controls was $1.46 \pm 1.01 \mathrm{mIU} / \mathrm{lit}$ as compared to $1.86 \pm 1.99 \mathrm{mIU} / \mathrm{lit}$ in pregnant woman without any statistical difference $(\mathrm{p}=0.56)$ (Table 3$)$.

\section{DISCUSSION}

Although DEXA scan of lumber region and hip is considered gold standard for non-invasive measurement of bone mineral density but these are not feasible in pregnant ladies. DEXA scan of distal forearm is a reasonably good alternative to estimate bone mineral content in pregnant women. ${ }^{4}$ The results varied in different studies (Table 4).

Table 4: BMD changes at forearm during pregnancy in different studies. ${ }^{4-13}$

\begin{tabular}{|c|c|}
\hline Author & BMD findings at forearm \\
\hline $\begin{array}{l}\text { Christiansen } \\
\text { et } \mathrm{al}^{4}\end{array}$ & No significant change \\
\hline Lamke et al ${ }^{12}$ & $\begin{array}{l}4.2 \% \text { fall in BMD at distal radius and } \\
\text { ulna(p<0.05) } \\
2 \% \text { increase in BMD at proximal } \\
1 / 3 \text { rd radius(Not Significant) }\end{array}$ \\
\hline $\begin{array}{l}\text { Drinkwater et } \\
\mathrm{al}^{13}\end{array}$ & $\begin{array}{l}2.2 \% \text { decrease in BMD of the radial } \\
\text { shaft but not in distal part. }(\mathrm{p}<0.05)\end{array}$ \\
\hline Kent et $\mathrm{al}^{7}$ & No significant change \\
\hline Cross et $\mathrm{al}^{8}$ & No significant change \\
\hline $\begin{array}{l}\text { Kolthoff et } \\
\mathrm{al}^{14}\end{array}$ & $\begin{array}{l}2 \% \text { decrease at ultra-distal radius } \\
(\mathrm{p}<0.001) \text { and no significant change } \\
\text { at proximal one third radius }\end{array}$ \\
\hline Lorrene et $\mathrm{al}^{9}$ & No significant change \\
\hline Naylor et al ${ }^{16}$ & $\begin{array}{l}2.8 \% \text { increase in BMD of arms }(\mathrm{p}= \\
0.01)\end{array}$ \\
\hline More et al ${ }^{17}$ & $\begin{array}{l}\text { Significant fall }(\mathrm{p}<0.001) \text { of } 3.8 \% \text {.in } \\
\text { BMD at ultra-distal } \\
\text { radius and proximal one third radius }\end{array}$ \\
\hline Ulrich et al $^{15}$ & $\begin{array}{l}1.2 \% \text { increase at proximal } 1 / 3^{\mathrm{r}} \mathrm{d} \\
\text { radius }(\mathrm{p}<0.05) \\
1.8 \% \text { decrease at ultra-distal radius } \\
\text { (Not Significant) No significant } \\
\text { change in total BMD }\end{array}$ \\
\hline Present study & $\begin{array}{l}1.4 \% \text { decrease at ultra-distal radius } \\
\text { (Not Significant) } \\
1.5 \% \text { increase at proximal one third } \\
\text { radius (Not Significant) } \\
\text { No significant change in total BMD }\end{array}$ \\
\hline
\end{tabular}

It was shown in the prior studies that peak bone mass is achieved in third decade of life and after that there is a gradual fall in the bone mass at the rate of $1-3 \%$ per decade of life till menopause and after menopause this rate further increases. Some investigators found higher bone loss in adolescent mothers as compared to adults; as their own body requirement is high during adolescence. ${ }^{5}$ While some other quoted that incidence of osteoporosis and osteopenia during pregnancy does not significantly increases with advancing age. ${ }^{6}$ In present study there was $1.4 \%$ decrease in BMD at ultra-distal radius and $1.2 \%$ gain in BMD at proximal one third radius which were not stastically significant. There was no change in BMD at mid radius and in total BMD of forearm; the results being comparable to other studies. ${ }^{7-9}$ Our results strengthen the assumption that increased demand of calcium during pregnancy is met mainly by increased calcium absorption rather than bone resorption. Kent et al found that there is increased intestinal 1,25-dihydroxyvitamin-D levels leading to enhanced absorption of calcium during pregnancy. ${ }^{7}$ High levels of estrogen lead to increased bone formation during pregnancy and the pre-ovulatory rise of estrogen has been found to induce endosteal bone growth in animal studies. Slight non- significant increase in bone mineral at proximal third of the radius supports the hypothesis of building up of mineral stocks for future lactation; during pregnancy itself and this was also seen in animal models. Heaney et al, concluded that pregnancy appears to be a state of positive calcium balance. ${ }^{10}$ Sowers et al, showed in a study that bone mineral density loss during lactation is recovered during pregnancy also in those who breast fed for prolonged period and got pregnant during lactational period, when bone mass was still low. ${ }^{11}$ Insignificant fall in BMD at ultra-distal radius support the view that probably there is bone mineral redistribution during pregnancy and bone density decreases at trabecular bone and increases at cortical portion so that cortical thickness of the long bones increases during pregnancy. Many researchers also reported such site specific differences in bone mineral changes as we noticed in our observation. ${ }^{12-15}$ Lamke et al, found that although trabecular bone constitutes only twenty per cent of the skeleton but it is more active metabolically and reflects changes in calcium metabolism earlier than cortical counterpart. ${ }^{12}$ However many other researchers found significant decrease in bone mineral density at one or more sites of forearm in their research work. $^{12-17}$

The mean serum calcium in pregnant women was $2.28 \pm 0.065 \mathrm{mmol} / \mathrm{lit}$ as compared to $2.45 \pm 0.58 \mathrm{mmol} / \mathrm{lit}$ in controls and was significantly lower $(\mathrm{p}=0.001)$. There are a lot of studies on investigating markers of bone turnover showing that bone turnover is increased during pregnancy and especially during last trimester. These studies showed that total serum calcium concentration is significantly decreased during third trimester though ionized calcium concentration remains the same as in our observation. Speculation is that there is maximum calcium transfer through placenta to fetus occur during this period leading to this decrease. This fall could be because of lowered serum albumin concentration which usually occurred during pregnancy and also seen in our results. Results of present study were consistent with 
results of Lorrene et al, who found significantly lowered serum calcium $(\mathrm{p}<0.05)$ at the end of second and third trimester and nadir at the end of second trimester. ${ }^{9}$ Ulrich and coworkers found that the increase in bone resorption was accompanied by a significant $(\mathrm{p}<0.002)$ decrease in serum calcium within the normal reference range in the third trimester. ${ }^{15}$ It is assumed that the calcium transfer to the fetus also peaks in the last trimester. ${ }^{18}$ Therefore, they speculated that the maternal serum calcium is decreased due to placental transport. In contrast More et al, Zeni et al found no significant difference in their studies. ${ }^{17,19}$

Mean serum Alkaline phosphatase concentration in pregnant woman was statistically higher $(\mathrm{p}=0.001)$ as compared to controls. The increase in serum total alkaline phosphatase concentration during pregnancy has been shown by other investigators as wel. ${ }^{16-18,20,21}$ Some researchers found linear increase while other found biphasic increase. Ulrich et al, showed a biphasic pattern with decrease from base line to first trimester followed by a significant increase in the third trimester and postpartum. ${ }^{15}$ This being cross sectional we could not tell the pattern of rise. The result of the present study agreed well with the cross et al, they found that ALP was significantly higher $(\mathrm{p}=0.001)$ especially during third trimester. ${ }^{8}$ Valenzuela reported an increase in bone specific alkaline phosphatase as early as by $10-12$ weeks of gestation. ${ }^{20}$ In agreement to present study Zeni et al, found that serum alkaline phosphatase was increased significantly during last two trimesters and highest increment was observed during third trimester. ${ }^{19}$

\section{CONCLUSION}

Osteopenia and osteoporosis are the major bone morbidities in women and these morbidities usually occur after menopause. Pregnancy is the state of high bone turnover. Bone mineral densitometric studies provide an opportunity to study the contribution of pregnancy to bone morbidities and to assess the preventive measures.

The present study concludes that bone mineral density did not decreased significantly during pregnancy and there is no apparent effect of pregnancy on bone mineral content .To further confirm the role of pregnancy on bone mineral reserve; it is needed to evaluate the serial BMD thoroughly at other sites also, and to comment upon whether these changes in BMD are transient or permanent, more extended period of study is required and it is suggested that the bone mineral contents to be measured at multiple sites longitudinally from prepregnancy till post-weaning, when all the possible hormonal changes have been settled.

\section{ACKNOWLEDGMENTS}

Authors would like to the patients and their colleagues for all their support.
Funding: No funding sources

Conflict of interest: None declared

Ethical approval: The study was approved by the Institutional Ethics Committee

\section{REFERENCES}

1. Widdowson EM. in: Scientific foundation of paediatrics.Davis JA and Dobbings J(eds)Wm Heinemann Medical Books: London; 1998.

2. Kovacs SC. Calcium and bone metabolism during pregnancy and lactation. J Mamm Gland Bio Neo 2005;10(2):105-18.

3. Kovacs CS, Kroneberg HM. Maternal-fetal calcium and bone metabolism during pregnancy, puerperium and lactation. Endocr Rev. 1997;18(6):832-72.

4. Christiansen C, Roedbro R, Heinild B. Unchanged total body calcium in normal human pregnancy. Acta Obstet Gynecol Scand. 1976;55:141-3.

5. Sowers MF, Scholl T, Harris L, Jannausch M. Bone loss in adolescent and adult pregnant women. Obstet Gynecol. 2000;96:189-93.

6. Priti K, Chandravati, Khattar R. Bone morbidity in pregnant women. J Obstet Gynecol India. 2005;55(5):434-5.

7. Kent GN, Price RI, Gutteridge DH, Smith M. Allen JR, Barnes MP. Human lactation-forearm trabecular bone loss, increased bone turnover and renal conservation of calcium and inorganic phosphate with recovery of bone mass following weaning. J Bone Miner Res. 1990;5(4):361-9.

8. Cross NA, Hillman LS, Allen SH, Krause GF. Calcium homeostasis and bone metabolism during pregnancy, lactation and weaning; a longitudinal study. Am J Clin Nutr. 1995;61:514-23.

9. Ritchie LD, Fung EB, Halloran BP. A longitudinal study of calcium homeostasis during human pregnancy and lactation and after resumption of menses. Am J Clin Nutr. 1998;67(4):693-701.

10. Heaney RP, Skillman TG. Calcium metabolism in normal human pregnancy. J Clin Endocrinol. 1971;33:661-70.

11. Sowers M, Randolph J, Shapiro B, Jannausch M. A prospective study of bone density and pregnancy after an extended period of lactation and bone loss. Obstet Gynecol. 1995;85:285-9.

12. Lamke B, Bruindin J. Moberg P. Charges of bone mineral content during pregnancy and lactation. Acta Obstet Gynecol Scand. 1977;56 (3);217-9.

13. Drinkwater BL, Chesnut $\mathrm{CH}$. $3^{\text {rd }}$ - bone density changes during pregnancy and lactation in active women; a longitudinal study. Bone Miner. 1991;14(2):153-60.

14. Kolthoff N, Eiken P, Kristensen B, Nielsen SP. Bone mineral changes during pregnancy and lactation: a longitudinal cohort study. Clin Sci. 1998;94:405-12.

15. Ulrich U, Miller PB, Eyre DR, Chesnut $\mathrm{CH}$, Schlebusch $\mathrm{H}$. Bone remodeling and bone mineral density during pregnancy. Arch Gynecol Obstet. 2003;268:309-16. 
16. Naylor KE, Iqbal P, Fledelius C, Fraser RB, Eastell $\mathrm{R}$. The effect of pregnancy on bone density and bone turnover. J Bone Miner Ras. 2000;15(1):129-37.

17. More C, Bettembuk P, Bhattoa HP, Balogh A. The effects of pregnancy and lactation on bone mineral density. Osteoporos Int. 2001;12:732-7.

18. Hosking DJ. Calcium homeostasis in pregnancy. Clin Endocrinol. 1996;45:1-6.

19. Zeni SN, Ortela Soler CR, Lazzari A, Lope ZL. Interrelationship between bone turnover markers and dietary calcium intake in pregnant women: a longitudinal study. Bone. 2003;33(4):606-13.

20. Valenzuela GJ, Munson LA, Tarbaux NM, Farley JR. Time-dependent changes in bone, placental, intestinal and hepatic alkaline phosphatase activities in serum during human pregnancy. Clin Chem. 1987;33(10):1801-6.

21. Black AJ, Topping J, Durham B, Farquharson RG, Fraser WD. A detailed assessment of alterations in bone turnover, calcium homeostasis in normal pregnancy. J Bone Miner Res. 2000;15(3):557-63.

Cite this article as: Sharma R, Garg D, Khan $H$. Bone mineral changes during pregnancy: a crosssectional study. Int J Reprod Contracept Obstet Gynecol 2019;8:2172-7. 